\title{
ROMPENDO O SILÊNCIO: A IMPORTÂNCIA DA RESISTÊNCIA DAS MULHERES CONTRA AS DITADURAS NO BRASIL E NA ARGENTINA
}

\author{
BREAKING THE SILENCE: THE IMPORTANCE OF WOMEN'S RESISTANCE
}

AGAINST THE DICTATORSHIPS IN BRAZIL AND ARGENTINA

\begin{abstract}
Pós-Doutorado em Direito pela Università Degli Studi di Roma Tre (2012), Doutorado em Direito pela UNISINOS (2008), Mestrado em Direito pela Universidade Federal de Santa Catarina (2001), Graduação em Direito pela Universidade Regional do Noroeste do Estado do Rio Grande do Sul - UNIJUÍ (1998). Professor dos Cursos de Graduação, Mestrado e Doutorado em Direito na Universidade Regional do Noroeste do Estado do Rio Grande do Sul - Unijui e professor no Curso de direito da Faculdade Cnec Santo Ângelo.
\end{abstract}

Carla Doró de Oliveira

Mestrado em Direitos Humanos pela Universidade Regional do Noroeste do Estado do Rio Grande do Sul - UNIJUI (2017), Graduação em Direiro pelo Instituto Cenecista de Ensino Superior de Santo Ângelo - IESA (2015).

\begin{abstract}
Resumo
A história das mulheres é, não raras vezes, esquecida e desvalorizada, ainda mais quando se fala nos regimes ditatoriais vividos pelos países do Cone Sul. Assim, dando especial foco para o Movimento Feminino pela Anistia (MFA) e para a associação das Madres e Abuelas de Plaza de Mayo, este trabalho se propõe a analisar a participação das mulheres na organização de grupos civis de proteção aos direitos humanos durante o período autoritário vivido no Brasil e na Argentina. Para mais, procurou-se entender como tais organizações surgiram, como atuaram e quais foram as consequências dessa mobilização. $\mathrm{Na}$ metodologia utilizou-se pesquisa bibliográfica, numa abordagem histórico-dialética, abrangendo a leitura e análise de obras doutrinárias e artigos. Os resultados do trabalho apontam que a participação das mulheres na luta contra repressão foi inovadora, pois ia de encontro ao que se esperava da mulher nas décadas de 1960 e 1970. Apesar da pouca importância dada pelas narrativas históricas para esses grupos de mulheres, observa-se que sua atuação foi de fundamental importância para a superação do regime autoritário nos países estudados.
\end{abstract}

Palavras-chave: Direitos Humanos. Ditadura Militar. Mulheres. Resistência. 


\begin{abstract}
Women's history is frequently forgotten and devalued, and it happens more often when we are studying dictatorships that occurred in Latin American countries. Thus, with special focus on the Feminine Movement for Amnesty (MFA) and on the Madres e Abuelas de Plaza de Mayo, this study aims to analyze women's participation in the organization of human rights protection's civil groups during the dictatorial period that took place in Brazil and in Argentina. Furthermore, this research tries to understand how those groups emerged, how they acted and what the consequences of their mobilization were. In the methodology, we used bibliographic research, in a qualitative approach, including the reading and analysis of doctrinal works and articles. Our results indicate that the women's participation on the opposition was innovative, because it went against how society expected women to act in that period. Although the little importance given by the historical narratives to those groups of women, we observed that their actuation was extremely important to overcome the dictatorship in the countries in analysis.
\end{abstract}

Key-words: Dictatorship; Human Rights; Resistance; Women.

\title{
1. CONSIDERAÇÕES INICIAIS
}

Muito se conhece da história das ditaduras vividas pelos países latinoamericanos: como e por que começaram, de que forma se desenvolveram, quem eram seus heróis e seus vilões. Ouvimos falar de João Goulart, de Marighella, de Castello Branco e de Costa e Silva. No entanto, pouco se sabe sobre as mulheres que ajudaram a escrever a história do país. Quem foram, como agiram, por que lutaram e onde chegaram: esses são alguns dos questionamentos que nos moveram a pensar sobre a participação das mulheres na resistência à ditadura no Brasil e na Argentina.

Não se duvida da importância dos movimentos sociais na mobilização da população em prol de um objetivo comum. Sabemos que a anistia, em nosso país, foi uma bandeira erguida, primeiramente, pelo povo e, então, adotada pelo governo embora não nos moldes inicialmente pretendidos pela sociedade. Entretanto, embora o pontapé inicial da luta pela anistia tenha sido dado por mulheres, esse não é considerado um fato relevante nas narrativas históricas, as quais se limitam a citar a participação feminina no soerguimento dessa bandeira.

No país vizinho, a mesma tendência pode ser observada: foram as mulheres - mães, avós, esposas de desaparecidos políticos - que iniciaram a oposição ao regime militar vivido na Argentina. O movimento, hoje conhecido como Madres e Abuelas de Plaza de Mayo, todavia, conta com um prestígio consideravelmente maior 
quando em comparação com o nosso país, tendo sido um dos principais responsáveis pela queda do regime militar argentino.

$\mathrm{Na}$ realização da pesquisa utilizou-se dos métodos fenomenológicos e do procedimento monográfico. Nesse cenário, para o desenvolvimento do estudo, procedeu-se à seleção de bibliografia e documentos afins à temática em meios físicos e na internet, realizando-se, após a leitura, o fichamento do material selecionado, objetivando à reflexão crítica sobre o conteúdo, com a consequente exposição dos resultados obtidos através de um texto escrito monográfico. É de se salientar a interdisciplinaridade da presente pesquisa, a partir da utilização de conceitos provenientes de diferentes áreas do conhecimento.

Diante disso, procura-se, pelo presente trabalho, analisar a importância dos movimentos de mulheres iniciados durante a repressão no Brasil e na Argentina para a superação dos regimes autoritários vividos por esses países, bem como para o fortalecimento da democracia e o respeito aos direitos humanos. Não obstante, buscase analisar quais as consequências da atuação desses grupos quando da redemocratização dos países em análise. A partir disso, espera-se contribuir na reflexão sobre a história das mulheres no Brasil e na Argentina, bem como, para uma melhor compreensão da história desses países, especialmente no que se refere à superação das ditaduras e a redemocratização das instituições.

\section{UM OUTRO MUNDO É POSSÍVEL}

Pensar sobre direitos humanos, na esteira do pensamento de Joaquín Hererra Flores (2009), é pensar o novo, é problematizar. O autor explica que a condição humana não é eterna e universal, diferentemente do que o pensamento moderno nos faz crer, mas que a universalidade é, pelo contrário, uma forma de simplificação da condição humana, a fim de afirmar uma pretensa igualdade.

Nesse sentido, conforme André Leonardo Copetti Santos e Doglas Cesar Lucas (2015, p. 45) "tivemos, assim, ao longo da Modernidade, o predomínio de uma igualdade formal", igualdade essa que acabou por reafirmar um sistema opressivo que dá voz e vez a apenas um sujeito que se encaixa em determinados padrões. Como bem assinala Ana Alice Alcântara Costa (2010, p. 175), "a conquista da igualdade formal não foi capaz de mudar os parâmetros da subordinação feminina, já que as mulheres seguiam sendo vistas e tratadas como inferiores". 
Para Herrera Flores (2009), então, os direitos humanos precisam ser reinventados a fim de possibilitarem verdadeiras mudanças na prática social. Nesse sentido, os direitos humanos devem servir de instrumento para a construção de um espaço de luta social onde as vozes antagonistas sejam ouvidas. Assim, faz-se imprescindível o empoderamento os sujeitos que estão excluídos dessa ideologia universal. Nessa lógica, os movimentos sociais adquirem especial importância. Por isso o interesse na análise acerca da participação das mulheres na resistência contra regimes autoritários.

Para Frantz Fanon (apud FLORES, 2009, p. VII), faz-se necessário abandonar "essa Europa que não para de falar no homem, ao mesmo tempo que o massacra onde quer que o encontre, em todos os cantos de suas ruas limpas, em todos os cantos do mundo". É com esse pensamento que Joan Scott (1992, p. 77) argumenta que "reivindicar a importância das mulheres na história significa necessariamente ir contra as definições de história e seus agentes já estabelecidos como 'verdadeiros"'.

A ideia de direitos humanos como instrumento contra-hegemônico num cenário de opressão e dominação vai, justamente, ao encontro dos movimentos liderados por mulheres em prol da redemocratização de seus países, pois

Os direitos humanos foram categorias que, em determinados momentos e sob determinadas interpretações, cumpriram um papel legitimador desse novo sistema de relações; e em outros momentos e sob outras interpretações, desempenharam o papel de mobilização popular contra a hegemonia das relações que o capital veio impondo durante seus cinco séculos de existência (FLORES, 2009, p. 3).

Assim, ao se agruparem durante um período de exceção contra um governo autoritário e opressor, assumindo justamente sua condição de mulheres - seus papéis de mães, esposas, filhas, irmãs - e desafiando a ordem imposta, as organizações de mulheres desempenharam uma função fundamental na luta pelos direitos humanos e pela democracia.

Simone de Beauvoir (1991, p. 172) afirma que os direitos abstratos "nunca bastaram para assegurar à mulher uma influência concreta sobre o mundo". Nessa perspectiva, necessário romper com essa abstração e colocar, de modo efetivo, os direitos em prática. Nesse contexto, identificar a mulher como sujeito político, colocála em lugar de protagonista da história, significa ressignificar o estereótipo reproduzido da mulher enquanto indivíduo naturalmente submisso e dócil. 


\title{
2.1. A VOZ SILENTE DA HISTÓRIA
}

"O mundo sempre pertenceu aos machos" afirma Simone de Beauvoir (1991, p. 81) em sua célebre obra "O segundo sexo". Para essa autora, "a alteridade é uma categoria fundamental do pensamento humano. Nenhuma coletividade se define nunca como Uma sem colocar imediatamente a Outra diante de si" (BEAUVOIR, 1991, p. 11). Nesse sentido, "o homem só se pensa pensando o Outro: apreende o mundo sob o signo da dualidade" (BEAUVOIR, 1991, p. 89).

Nessa senda, a alteridade pressupõe uma reciprocidade, já que, por exemplo, o estrangeiro é o outro em relação ao nacional, o judeu em relação ao antissemita, o negro em relação ao racista. No entanto, o estrangeiro, o judeu, o negro - e outras minorias - em certo momento vencem a opressão e se colocam na posição de sujeito, caracterizando o outro em relação a si. Porém, tal reciprocidade não se verifica na relação entre homem e mulher. A mulher é o outro em relação ao homem, mas o homem não é o outro para a mulher, porquanto "a mulher não se reivindica como sujeito, porque não possui os meios concretos para tanto, porque sente o laço necessário que a prende ao homem sem reclamar a reciprocidade dele, e porque, muitas vezes, se compraz no seu papel de Outro" (BEAUVOIR, 1991, p. 15). É com esse pensamento que Beauvoir chama a mulher de o Outro absoluto, pois não se coloca como sujeito histórico, não reivindica para si o papel de protagonista. Assim,

\begin{abstract}
Nesse quadro de dominação vamos encontrar, na posição de dominadores, tanto homens brancos europeus, quanto homens negros africanos; vamos presenciar não só a dominação patriarcal comum a países árabes, mas também presente no extremo oriente; presenciaremos, no mundo contemporâneo, estados de dominação patriarcal com justificação religiosa não só por cristãos americanos e europeus, mas também por muçulmanos e hindus da metade oriental do planeta (SANTOS; LUCAS, 2015, p. 37).
\end{abstract}

Sendo a mulher o outro absoluto, o homem, seja ele branco ou negro, cristão, muçulmano ou judeu, rico ou pobre, encontrará razões para subjugá-la. "'Bendito seja Deus nosso Senhor e o Senhor de todos os mundos por não me ter feito mulher", dizem os judeus nas suas preces matinais" (BEAUVOIR, 1991, p. 16). Platão também era grato aos deuses pelo "fato de ter sido criado livre e não escravo e, a seguir, o de ser homem e não mulher" (BEAUVOIR, 1991, p. 16).

A história foi feita pelos homens e, a seguir, contada por eles. Os avanços que possibilitaram melhoras na condição da mulher - como os métodos contraceptivos - 
foram em geral idealizados, planejados e executados por homens. "Trabalhadora ou ociosa, doente, manifestante, a mulher é observada e descrita pelo homem. Militante, ela tem dificuldade em se fazer ouvir pelos seus camaradas masculinos, que consideram normal serem seus porta-vozes" (PERROT, 1988, p. 186).

Na história, a mulher raramente ocupa o lugar de protagonista. À exceção de algumas poucas mulheres exaltadas pelos historiadores, à mulher é relegado o plano privado, o "backstage", jamais o palco. Nesse sentido, Dora Barrancos (2008, p. 12, tradução nossa) afirma que, "mais além desse reconhecimento às 'grandes mulheres', o balanço final indica uma notória ausência da ação feminina, como se tivesse sido possível uma história sem as mulheres". Da mesma forma, Perrot (2005, p. 322) assevera "auditoras ou espectadoras, as mulheres constituem a plateia. Mas têm muito mais dificuldade para subir ao palco". A existência desse número reduzido de grandes mulheres nos relatos históricos demonstra que "não foi a inferioridade feminina que determinou sua insignificância histórica: sua insignificância histórica foi que as votou à inferioridade" (BEAUVOIR, 1991, p. 170-1).

Nesse sentido, reivindicar a importância das mulheres é dar-Ihes condições de assumir um papel de protagonismo na história. É dar-Ihes possibilidades para que se reconheçam enquanto sujeitos. Assim, a história das mulheres "questiona a prioridade relativa dada à 'história do homem', em oposição à 'história da mulher', expondo a hierarquia implícita em muitos relatos históricos" (SCOTT, 1992, p. 78).

Proibidas de participar da vida pública, do mundo político, as mulheres ocupavam os espaços privados. Se ao homem cabia à direção da cidade, à mulher foi delegado o cuidado da casa, o zelo pelas crianças, pelos doentes. Desse modo, "valoriza-se" a "função natural da mulher" sem, contudo, dar-Ihe efetivo reconhecimento e espaço para que desenvolva um papel de importância na vida política (PERROT, 2005).

Quando as mulheres precisam trabalhar, explica Scott (1991), ocupavam funções "condizentes" com suas habilidades e capacidades físicas, o que a autora chama de "trabalho de agulha". Perrot também observa claramente essa distinção que determina o que seria uma "profissão de mulher". Segundo a autora, "ensinar, tratar, assistir: esta tripla missão constitui a base de 'profissões femininas'” (PERROT, 1991, p. 508). Essas qualidades reais são fantasiadas como "qualidades naturais", produto de uma suposta feminilidade, como se a mulher somente pudesse desenvolver um certo tipo de atividades, as quais seriam "proibidas" aos homens, porque inferiores. 
Importante enfatizar que, na percepção de Perrot $(2005$, p. 258 ) "as mulheres desvalorizam tudo o que tocam [...]. Os setores em que elas entram são progressivamente desertados pelos homens que preferem reconstruir, em outros lugares, espaços masculinos intactos". Nessa perspectiva, Scott (1991) explica que a visão normalmente difundida era de que as mulheres eram naturalmente dependentes - enquanto solteiras, dos pais, depois de casadas, dos maridos - e, portanto, seu salário deveria ser naturalmente menor que o dos homens, uma vez que não passaria de complemento à renda masculina.

Uma vez internalizados os atributos supostamente femininos, as mulheres, quando operárias, relutavam em fazer greves, uma vez que tais atos contrariavam todos os "atributos da mulher", não eram, portanto, naturais, já que "ousar fazer greve é afrontar a opinião, sair da fábrica, comportar-se como mulheres públicas" (PERROT, 1991, p. 513). Assim, consoante Perrot (2005), inicialmente, as mulheres preferiam aderir às greves mistas - que reuniam homens e mulheres. Logo, as reivindicações geralmente se resumiam em pedidos por melhores condições de trabalho e não ainda por igualdade das condições entre homens e mulheres. A tendência à submissão levava as grevistas a recorrer frequentemente às autoridades pedindo permissão para iniciar uma greve. Ademais, as mulheres não tinham uma organização sindical e, assim, não contavam com o apoio dos operários homens em suas reivindicações, que inclusive the encaravam como uma ameaça, em razão da mão de obra barata que ofereciam. Essa visão também é compartilhada por Scott (1991, p. 464), segundo a qual os sindicalistas "aceitavam como inevitável o fato de os salários femininos serem mais baixos que os masculinos, e por isso tratavam as mulheres trabalhadoras mais como uma ameaça do que como potenciais aliadas".

Condenadas ao âmbito privado e às "profissões de agulha", a voz das mulheres foi silenciada e proibida. O papa Honório III sentenciou "as mulheres não podem falar. Seus lábios carregam o estigma de Eva, que foi a perdição dos homens" (GALEANO apud SANTOS; LUCAS, 2015, p. 19). Assim, "o Verbo é o apanágio dos que exercem o poder. Ele é o poder. Ele vem de Deus. Ele faz o homem. As mulheres estão excluídas do poder, político e religioso. No paraíso, Eva perverteu definitivamente a palavra das mulheres" (PERROT, 2005, p. 318).

No entanto, a passos lentos, as mulheres vão reivindicar o direito da fala, o direito de serem ouvidas. Executando, inicialmente, os trabalhos que the são permitidos, ingressando, quando possível, nos sindicatos permeados de homens, 
cumprindo com dedicação seus "papéis", chega o momento em que as mulheres subvertem a ordem imposta e se fazem ouvir, mesmo no silêncio, mesmo que apenas marcando sua presença constante na rua e na praça. Se, conforme Perrot (2005, p. 464) "restaurar a ordem é impor silêncio às mulheres", é preciso derrubar essa "ordem", ouvindo a voz das mulheres, notando sua presença, a fim de mudarmos a história para mudarmos o rumo da história.

Da mesma forma como foram coibidas de participar do mundo público e político, as mulheres também foram privadas das narrativas históricas. Conforme Michelle Perrot (1988, p. 186) "o silêncio sobre a história das mulheres também advém do seu efetivo mutismo nas esferas políticas, por muito tempo privilegiadas como os locais exclusivos do poder". No entanto, as mulheres ocuparam outros lugares, "elas traçam um caminho que é preciso reencontrar. Uma história outra. Uma outra história" (PERROT, 1988, p. 212).

Contar essa outra história vivida pelas mulheres, na qual elas são protagonistas, é o objetivo desse trabalho. Durante o período autoritário vivido por diversos países latino-americanos, observa Cristina Wolff (2015, p. 981), "a figura da mãe com o retrato de seu filho no peito tornou-se paradigmática. As mães da Plaza de Mayo, dona Zita, Zuzu Angel, mães chilenas, uruguaias, paraguaias, bolivianas foram às prisões, saíram nas ruas, escreveram cartas, choraram". Assim, é essa história que nos interessa. A história de mulheres que desafiaram a ordem - tanto jurídica como "natural" - lutando por seus direitos e para derrubar regimes opressores, lutando para ter voz.

\subsection{A LUTA PELA ANISTIA NO BRASIL: UMA BANDEIRA ERGUIDA PELAS MULHERES}

No Brasil e na América Latina as mulheres também foram excluídas da história. Os heróis de nossa pátria usam calças, têm barba e bigode. Contudo, aos poucos a narrativa feminina vem sendo descoberta em nosso país. De acordo com Ana Maria Colling (1997, p. 115-6), "a história da repressão durante o período da ditadura militar é a história dos homens. A mulher militante política não é encarada como sujeito histórico, sendo excluída do jogo do poder, porque o poder é masculino". No entanto, as mulheres desempenharam um papel fundamental na resistência à ditadura militar no Brasil - bem como na Argentina, como se verá nesse trabalho -, 
especialmente na organização sociedade civil em prol da luta pela anistia, pela redemocratização e pelo esclarecimento dos crimes cometidos pelo governo autoritário.

Na década de 1970 no Brasil vivia-se um turbilhão e vários foram os motivos que levaram os militares a, lentamente, deixar o governo. A crise econômica, a pressão da Igreja Católica, de países estrangeiros e de organizações internacionais de proteção aos direitos humanos, da Ordem dos Advogados do Brasil, bem como da população civil, que passa a se organizar em torno da bandeira pela anistia ampla e geral aos presos políticos e exilados, são alguns dos motivos que podem ser citados.

Nesse sentido, é interessante observar que a elite da sociedade brasileira sempre gozou da complacência dos órgãos estatais quando da apuração e punição de seus crimes. Para mais, a classe média foi a principal apoiadora do golpe de 1964 . Segundo Marcelo Siqueira Ridenti (1990, p. 117),

Foram criados grupos femininos conservadores para "arregimentar a opinião pública pra o golpe militar de 1964", nos principais estados e cidades do país, grupos que revelariam grande capacidade mobilizadora, por exemplo, por ocasião das "Marchas da Família com Deus pela Liberdade" que, lideradas pelas mulheres na sua fachada, arrastaram milhares de pessoas às ruas de todo o país, antes e logo depois do golpe, contando com adesão de religiosos, de governos estaduais e municipais, bem como do empresariado, inclusive com dispensa do serviço e facilidades de transportes, o que explica parcialmente a participação maciça, naqueles eventos, de camadas sociais médias diferenciadas e até de operários, ligados à Igreja.

No entanto, conforme Thomas Skidmore (2000, p. 246), nos porões da ditadura "elite e não-elite tinham o mesmo tratamento". E foi graças a isso que, aos poucos, as instituições acima mencionadas passaram a lutar veementemente contra o governo militar e contra as violações aos direitos humanos cometidas pelo Estado.

Nesse sentido, os dados colhidos pelo estudo realizado pelo projeto "Brasil: Nunca Mais" (1986, p. 86) revelam que, entre os acusados nos inquéritos que tramitavam durante a ditadura, "mais da metade havia atingido a universidade, num contexto nacional em que pouco mais de $1 \%$ da população chega até ela. Apenas 91 desses réus declararam-se analfabetos, e sabe-se que, no Brasil, estes atingem mais de 20 milhões entre os cidadãos maiores de 18 anos".

Esses dados demonstram que a repressão atingiu uma parcela bem específica da população brasileira. Sendo assim, quando os familiares dos acusados tomaram conhecimento do tratamento pelo qual os presos políticos passavam quando 
estavam sob custódia, quando ficou nítido o modo de agir do Estado, "essa repressão indiscriminada fez com que muita gente na elite reconsiderasse seu apoio ao governo militar" (SKIDMORE, 2000, p. 246).

Assim, diferentes grupos atuaram na luta em prol da anistia. Jessie Jane Vieira de Sousa (2011) reafirma a importância dos movimentos pela anistia promovidos pelos sindicados, pelos estudantes, mas principalmente pelas mulheres e pelos Comitês Brasileiros pela Anistia (CBAS). De acordo com a autora, o Movimento Feminino pela Anistia (MFA) foi um dos precursores na luta pela anistia, e buscava, principalmente, devolver os direitos dos servidores públicos que foram arbitrariamente cassados pelos militares, bem como visava à pacificação social, a reconciliação. Por sua vez, a proposta defendida pelos CBAS enveredava por outro caminho, uma vez que os Comitês buscavam a apuração dos delitos praticados pelos agentes da repressão durante o regime militar, bem como a responsabilização dos torturadores, com a revelação sobre a verdade acerca dos mortos e desaparecidos durante a ditadura.

É também nesse sentido que Janaína de Almeida Teles (2010, p. 71) expõe a ação das CBAS, afirmando que foi graças a tais grupos que a campanha pela anistia ampla, geral e irrestrita ganhou força, "em 1978, e se constituiu num movimento político que recebeu certo apoio popular promovendo extensa divulgação pública das denúncias sobre os abusos aos direitos humanos cometidos pela ditadura".

O que se deve destacar é que o slogan pela anistia ampla, geral e irrestrita defendida pela grande maioria da população simbolizava a luta pela anistia aos presos políticos, aos exilados, aos prejudicados pelas cassações de cargos públicos, mas também àqueles que demonstraram sua contrariedade ao regime militar por meio da luta armada.

Paralelamente, o governo vislumbrava nessas manifestações a possibilidade de iniciar a abertura política imaginada por Ernesto Geisel (Presidente do país de 1974 a 1979), então delegada ao seu sucessor, João Figueiredo. No entanto, conforme imaginada pelo general gaúcho, a transição do regime ditatorial para o democrático deveria ser "lenta, gradual e segura", e nada poderia ser mais seguro para o governo militar do que promulgar uma lei de anistia, ainda durante o regime autoritário, que beneficiasse os próprios agentes da repressão.

A anistia nos moldes desejados pelo Executivo não era ampla, geral e irrestrita, uma vez que não beneficiaria os militantes a quem o governo considerava 
"terroristas", por terem lançado mão do uso de armas na luta contra o regime militar. Ademais, para atender aos propósitos do governo, a anistia beneficiaria os militares envolvidos nas práticas de tortura, desaparecimentos forçados e mortes de presos políticos.

Nessa lógica, apesar de toda a mobilização social, foi o projeto de anistia restrita elaborado pelo governo que saiu vitorioso. Paulo Abrão (2011, p. 123) salienta que "o elemento do controle do regime volta a se fazer presente nesse momento, uma vez que um terço do Congresso Nacional era composto pelos chamados 'senadores biônicos', parlamentares indicados pelo próprio Poder Executivo".

É importante frisar que, apesar da vitória do projeto do Executivo, a mobilização da população, por meio das organizações civis como o MFA e as CBAS não foi em vão, pois o projeto apoiado pelo governo, mesmo tendo sido votado ainda durante a repressão, venceu por uma pequena margem de votos, conforme dados apresentados por Danyelle Nilin Gonçalves (2009). A ínfima diferença de votos que determinou a vitória do projeto apresentado pelo governo militar demonstra que a mobilização da população surtiu efeitos positivos, uma vez que, sem os votos dos "senadores biônicos", indicados pelo governo ditatorial e que compunham um terço do Senado, o resultado teria sido completamente diverso. Ademais, a união da sociedade em torno de uma mesma bandeira demonstrou a força da população e serviu para acelerar a redemocratização do país.

Nesse contexto, imperioso destacar a relevância do Movimento Feminino pela Anistia (MFA), surgido em 1975 no país, sob a liderança de Terezinha Zerbini. O MFA objetivava mobilizar a opinião pública em defesa dos presos políticos e pelo retorno dos exilados, a partir de uma anistia ampla e geral. Essa iniciativa que desafiou o governo militar, além de ter sido organizado por mulheres, foi "a primeira estruturação pública e oficial de questionamento da ditadura militar" (COSTA, 2010, p. 181). No entanto, essa posição de protagonismo adotada pelas mulheres na resistência contra o regime autoritário não encontra significativo espaço nas narrativas históricas sobre a luta contra a ditadura brasileira.

Cynthia Sarti (2001, p. 36) argumenta que "o Ano Internacional da Mulher, 1975, oficialmente declarado pela ONU, propicia o cenário para início do movimento feminista no Brasil, ainda fortemente marcado pela luta política contra o regime militar". No mesmo sentido explica Marianne Schmink (1981, p. 116, tradução nossa), "novos grupos emergiram em 1975 seguindo o estímulo do Ano Internacional da 
Mulher e a subsequente 'abertura' do debate político no Brasil".

Foi por meio desse movimento que "esposas, mães, filhas e companheiras saíram às ruas para denunciar as prisões, torturas, assassinatos e desaparecimentos dos atingidos pela repressão" (COLLING, 1997, p. 44). Para Joana Maria Pedro (2010, p. 126), o contato das mulheres com os presos e presas políticas, e a luta contra o aparelho repressor em busca de informações sobre os desaparecimentos políticos, fez com que algumas mulheres passassem a perceber "a especificidade de ser mulher, de atuar como mulher no espaço público".

Nessa perspectiva, a maternidade assume importante papel, uma vez que, essas mulheres, ao reproduzir o estereótipo da mãe que cumpre sua função com extrema dedicação e zelo, ou seja, ao seguir à risca os padrões impostos pela sociedade patriarcal, acabam justamente rompendo com esse modelo que exila a mulher ao âmbito privado ao saírem às ruas para exigir o fim das torturas e uma anistia ampla e irrestrita aos presos políticos. Conforme sintetiza Colling (1997, p. 44) "as mulheres começam a ocupar espaços exclusivamente masculinos". Nessa lógica, Cristina Wolff (2015, p. 979-80) assevera,

\begin{abstract}
As primeiras a aparecerem nesse cenário como sujeitos foram as mães. Como me disse, em conversa informal uma ex-presa política brasileira, o pesadelo de qualquer delegado de polícia era uma mãe. Quem poderia questionar o direito de uma mãe de saber sobre o destino de seu filho ou filha? Um sentimento construído tão fortemente em nossa cultura ocidental, como explicou Elisabeth Badinter, a ponto de ser considerado um "instinto", o instinto materno, algo que seria do campo da natureza. As mães se tornaram as primeiras porta vozes que adquiriram legitimidade inquestionável e sensibilizaram a opinião pública.
\end{abstract}

Essa mobilização de mulheres complicava a atuação por parte do governo, pois mesmo para durante um período de exceção era difícil "reprimir abertamente essas mulheres que se reivindicavam mães, esposas, donas de casa; ou seja, exatamente as performatividades que as ditaduras, as representações, a cultura, a religião esperavam delas" (WOLFF, 2015, p. 985).

Importante observar que, se em 1964 as mulheres se organizaram a fim de apoiar a instauração de uma ditadura militar, por meio da Marcha da Família com Deus pela Liberdade; com o transcurso de uma década, elas se reuniam em prol da democracia e do respeito aos direitos humanos. Esse "sentimento das mães foi capaz de despertar a empatia de muitos" (WOLFF, 2015, p. 982), inclusive da Igreja Católica que, finalmente, passa a interceder em prol dos presos políticos, dos torturados, 
desaparecidos e exilados, atuando em parceria com a população civil, especialmente com as organizações de mulheres.

A participação da Igreja na luta das mulheres foi de fundamental relevância para reforçá-la, especialmente por meio da Teologia da Libertação. No entanto, para Chyntia Sarti (1998), o apoio da Igreja Católica fez com que alguns assuntos polêmicos - a exemplo do aborto - fossem deixados de lado. Para além, outro aspecto negativo dessa parceria era a manutenção da ideia patriarcal do papel tradicional das mulheres nas famílias. Nas palavras de Michelle Perrot (1991, p. 530) "as religiões têm pesado como uma chapa de chumbo nos ombros das mulheres; mas têm-lhes concedido igualmente consolo e auxílio", esclarecendo que "quando a lgreja leva as mulheres para a política [...] é para reforçar um modelo familiar perfeitamente conservador" (PERROT, 1991, p. 530). Apesar disso, a parceria entre a Igreja Católica e as mulheres trouxe resultados importantes para a redemocratização do país, uma vez que garantiu a aprovação, juntamente com outras organizações civis e entidades, da Lei de Anistia.

Dessa maneira, a luta pela anistia, iniciada de forma pioneira pelas mulheres, possibilitou diversos avanços não apenas rumo à redemocratização do país, mas também na condição das mulheres brasileiras. Primeiramente, deve-se destacar que, graças a anistia conquistada, as exiladas puderam voltar ao país, o que favoreceu e impulsionou o crescimento do movimento feminista no país, pois "as exiladas traziam em sua bagagem [...] a influência de um movimento feminista atuante, sobretudo na Europa" (SARTI, 1998, p. 7). Esse retorno, por sua vez, possibilitou o início da reivindicação de demandas essencialmente feministas, como a discussão acerca da questão do gênero.

Nesse contexto, Joana Maria Pedro (2010) observa que o feminismo na América Latina, especialmente nos países que passaram por ditaduras militares, como o Brasil e a Argentina, tornou contornos distintos e que o contato das mulheres com a ideologia feminista se deu de forma variada. Conforme a autora, a maioria das mulheres "descobriu" o feminismo por meio da resistência contra a opressão dos regimes autoritários, e outras tantas relatam ter tido o primeiro contato com as ideias feministas em razão do exílio pelo qual tiveram de se submeter, e algumas até mesmo em razão de estudos acadêmicos. Assim, "o feminismo militante no Brasil surge como consequência da resistência das mulheres à ditadura, depois da derrota da luta armada e com o sentido de elaborar política e pessoalmente esta derrota" (SARTI, 
2001, p. 33).

O retorno das exiladas e a redemocratização do país, tendo estimulado o desenvolvimento do feminismo no país, também gerou um progresso nos direitos das mulheres. Nessa senda, em 1985 foi criado o Conselho Nacional dos Direitos da Mulher (CNDM), vinculado ao Ministério da Justiça, com o objetivo de promover políticas a fim de eliminar a discriminação contra a mulher e promover a igualdade entre os sexos. Esse Conselho atuou ativamente durante a Assembleia Nacional Constituinte, em conjunto com o movimento feminista e outras organizações e, por meio da campanha "Constituinte pra valer tem que ter palavra de mulher", conseguiu fazer aprovar $80 \%$ das propostas em prol dos direitos da mulher (COSTA, 2006).

\begin{abstract}
A novidade desse processo foi a atuação conjunta da chamada "bancada feminina". Atuando como um verdadeiro "bloco de gênero", as deputadas constituintes, independentemente de sua filiação partidária e dos seus distintos matizes políticos, superando suas divergências ideológicas, apresentaram, em bloco, a maioria das propostas, de forma suprapartidária, garantindo assim a aprovação das demandas do movimento (COSTA, 2006, p. 64).
\end{abstract}

Por todo o exposto, percebe-se que as mulheres desempenharam um papel fundamental - e, é preciso acrescentar, inovador - durante a ditadura militar no país. Inicialmente, assumindo uma posição conservadora, deram suporte ao Golpe de 1964. Posteriormente, rebelando-se contra a violência estatal, lutaram em prol da redemocratização do país, da anistia, e dos direitos humanos. Usando o discurso machista e patriarcal em seu favor, assumiram seu papel "natural" de mães para fazer valer seu direito à informação sobre o paradeiro de seus filhos. Conforme Michelle Perrot, "as mulheres souberam apoderar-se dos espaços que lhes eram deixados ou confiados para alargar a sua influência até as portas do poder" (PERROT, 1991, p. 503).

É fundamental observar que, de acordo com Renata Meirelles (2011, p. 112), quando as mulheres assumiam a luta contra o regime ditatorial, assumiam "não apenas o risco de estarem sujeitas à violência do aparelho repressor, mas também contrariar as expectativas relacionadas à condição feminina na sociedade dos anos 1960-70, isto é, questionar o papel feminino de dedicação ao lar e à família". No entanto, essas mulheres foram adiante, "criando, em especial, novos espaços de interlocução e atuação, possibilitando o florescer de novas práticas, novas iniciativas e identidades feministas" (COSTA, 2006, p. 76). Assim, salienta Marcelo Ridenti 
(1990, p. 122) "completava-se o quadro: nos anos 60 , das maneiras as mais diferenciadas, ainda que distantes de uma perspectiva propriamente feminista, as mulheres marcaram a cena política da sociedade brasileira".

Nas palavras de Maria Auxiliadora de Almeida Cunha Arantes (2010, p. 28) "ao longo da história do Brasil, a luta de resistência das mulheres é recorrente. Durante a ditadura civil-militar [...] as mulheres também foram protagonistas, como militantes da resistência e como organizadoras da sociedade civil para o retorno do país à democracia". No entanto, Nilcéa Freire (2010, p. 15) tem razão ao destacar que "o relato oficial sobre a nossa trajetória como nação é estritamente masculino". Por isso a importância de demonstrar que as mulheres brasileiras souberam, mesmo diante de um governo autoritário e opressor, patriarcal e anti-feminista, demonstrar que o pessoal é político, que o privado também é público. Expondo sua dor em suas reivindicações, exercendo o que se considera o seu "instinto materno", exigiram respostas, reclamaram o respeito aos direitos de seus familiares e o retorno à democracia.

Foi graças à iniciativa dessas mulheres que saíram de suas casas e ocuparam a rua, que deixaram o âmbito privado para tornar público o seu sofrimento que pudemos dar início à superação de um período tão traumático de nossa história. Embora quase nada se saiba sobre a história individual dessas mulheres, embora muito pouco se estude a importância da participação feminina na organização de grupos de direitos humanos voltados à luta pela anistia e pela democracia, devemos reconhecer sua existência e fundamental importância. Se a mulher não faz parte da história é porque não é encarada como sujeito histórico. Poucas vezes a mulher foi protagonista da história e, quando foi, raramente essa história é contada. É fundamental, então, que saibamos ouvir a essas mulheres que desafiaram a ordem ao se colocarem no palco dos acontecimentos.

\subsection{MADRES E ABUELAS DESAFIAM A DITADURA ARGENTINA}

Em se tratando da ditadura militar argentina, o contexto histórico que precedeu a ditadura iniciada em 1976 era de instabilidade política e de ânimos revoltados. Os recorrentes golpes militares no país, a Revolução Cubana, a Guerra do Vietnã e a morte de Che Guevara foram alguns dos fatores que sacudiram o mundo nesse período e que motivaram o surgimento de diversas organizações políticas de 
variadas ideologias, as quais eram em sua maioria na Argentina, partidárias do marxismo-leninismo.

Analisando a condição da mulher no período anterior à ditadura militar, Barrancos (2008) enfatiza que, a partir dos anos 1950 as mulheres passam a ser aceitas nas universidades argentinas, mas foi nas décadas de 1960 e 1970 que o número de universitárias cresceu de forma significativa. Segundo essa autora, a faculdade mais aberta às mulheres foi Medicina, assim como Odontologia. Logo a seguir aparecia a área das humanidades, com destaque para os cursos de Psicologia e Sociologia. Observar-se que tais áreas se encaixam melhor no perfil da "profissão de mulher", pois se dedicam a cuidar, ensinar, assistir, observar.

Foi a partir da década de 1960 a luta armada surgiu como alternativa para diversos grupos. Salienta-se que era grande o número de mulheres engajadas nessas organizações políticas, mas que, no entanto, a luta pela libertação das mulheres da opressão patriarcal era vista como uma questão a ser discutida depois da revolução (BARRANCOS, 2008).

É interessante considerar que as histórias argentina e brasileira se aproximam e se afastam em diversos pontos. Além dos sucessivos golpes de Estado vividos em ambos os países, o uso da violência também era contínuo tanto no Brasil quanto no país vizinho. No entanto, duas diferenças podem ser destacadas: em primeiro lugar, enquanto no Brasil o número de mortos e desaparecidos políticos é menor em comparação com o número de vítimas de tortura - 434 mortos e desaparecidos, conforme relatório da Comissão Nacional da Verdade (BRASIL, 2014) -, na Argentina as estatísticas apontam trinta mil mortos e desaparecidos (PEIXOTO, 2011); em segundo lugar, o aparelho estatal argentino lançava mal de outra prática da qual não se tem notícia na ditadura brasileira: a apropriação de crianças.

Segundo Samantha Viz Quadrat (2003), a apropriação de crianças filhos e filhas de militantes era um expediente muito utilizado pelo Exército argentino, existindo inclusive um manual que determinava os procedimentos a serem adotados. Conforme a autora, crianças de até 4 anos eram encaminhadas para orfanatos ou mesmo diretamente para famílias de militares que não podiam ter filhos. Nesses casos, a criança era registrada como se fosse filha do casal e toda a sua documentação anterior se perdia. A situação de crianças mais velhas era ainda pior, elas eram assassinadas, pois já estariam "contaminadas" pela subversão dos pais.

Piera Paola Oria (1987), em sua obra "De la casa a la plaza", estuda de forma 
aprofundada a instauração do regime militar argentino, a repressão contra os militantes, e a atuação das Madres e Abuelas de Plaza de Mayo na luta contra a ditadura. Segundo essa autora, as Madres, quando do Golpe em 1976, viviam uma vida privada, confinadas ao cuidado da família e da casa, à convivência familiar, com vizinhos e amigos. Quando começam a ouvir as notícias dos horrores ocorridos no país, sentem-se alienadas dessa realidade que não lhes pertence, que não lhes alcança. O relato de Hebe Bonafini (ORIA, 1987, p. 72-3, tradução nossa), uma das fundadoras da Associação das Madres, sintetiza bem essa realidade na qual se inseriam essas mulheres:

O que poderia fazer, exceto exclamar que barbaridade e examinar, no menor dos casos, o número de vítimas, a data do golpe? Nada se poderia corrigir, nem em nada participar. Para as mulheres as notícias da rádio, por mais sensacionalistas que fossem, não superavam o ruído ambiental que acompanhava o dos garfos lavados na cozinha, os pontos no tecido, o esguicho incessante de algum alimento. A cabeça estava sempre em outra parte. Assim, o mundo era uma fortaleza segura: os mortos não tinham nome porque a história era estrangeira.

Desse modo, o sentimento de impotência dominava as mulheres da época, acostumadas a "dar as costas" à vida pública. Essas mães, criadas dentro de uma estrutura socialmente determinada, ensinadas a cuidar do marido, dos filhos e da casa, e a manter-se distante dos assuntos políticos, nunca poderiam supor que seriam retiradas violentamente dessa realidade monótona da vida privada. Jamais esperavam que suas vidas saíssem daquela cotidianidade pré-estabelecida e já internalizada. Na visão de Oria (1987, p. 71, tradução nossa),

A mulher, nas sociedades atuais, tem como papel fundamental ser a reprodutora da força de trabalho, papel que, por outra parte, marca sua especificidade, Ihe reduzindo ao feito de cumprir com esse papel, no âmbito da vida cotidiana, pobre, rotineira e basicamente alienante, resignando-lhe a vivê-la como "verdadeiro destino".

Assim, as mulheres na época assimilavam seus papeis de mãe de forma automática e não-conflitiva, sem questionamentos. Somente quando se veem arrebatadas dessa cotidianidade com a qual estão acostumadas é que passam a enxergar outra realidade, que não a sua. A realidade em que se situa seu país. A realidade da ausência dos seus filhos. 
e começava sua problematização. O desaparecimento dos filhos e netos lhes lança com violência aos braços da história, a partir do "direito democrático e ingenuamente sagrado de querer saber" o que aconteceu com seus familiares (ORIA, 1987, p. 75, tradução nossa).

A extrema violência com a qual se deparam e a absoluta falta de informações faz com que as mães descubram o grau de sua alienação e as transforma, sem que elas mesmas percebam, em sujeitos políticos. Conforme o relato da Abuela Mirta Baravalle, passado um tempo de dor e isolamento depois do desaparecimento de familiares, um impulso a forçou a buscar respostas, sua obrigação de mãe falou mais alto: "em um segundo me dei conta de tudo: ou morro, ou luto, pensei. E nessa fração de segundos pensei o que jamais havia pensando em muitos anos" (ORIA, 1987, p. 77-8, tradução nossa). Segue a mesma lógica o depoimento da Abuela Antonia Segarra (ORIA, 1987, p. 77, tradução nossa):

Até que um dia saí; saí porque desde meu ponto de vista de mãe, avó e familiar de desaparecidos, desde que tomei conhecimento dos desaparecimentos, senti que como mãe tinha a obrigação de sair em busca dos meus filhos. Assim como os trouxe ao mundo, minha obrigação é trazêlos de volta para a vida, então continuarei buscando-os até o fim dos meus dias.

Foi a obrigação de mãe que Ihes arrancou da alienação. Foi o dever de cuidado que fez as Madres enfrentarem a realidade em busca de seus filhos. Na visão de Andrés Delgado (2012, p. 46, tradução nossa), “em 1977, as Madres de la Plaza de Mayo surgiram como uma forma de erguer uma voz que nunca antes tinha sido ouvida na vida política argentina, a voz das mulheres e das". Para Barrancos (2008, p. 148, tradução nossa), por sua vez, "foram as mulheres que levaram adiante a mais contundente das oposições à feroz ditadura que se extendeu entre 1976 e 1983, e que a fizeram cambalear".

Barrancos (2008) e Delgado (2012) explicam que as mães se conheceram durante a busca por informações sobre seus filhos desaparecidos e que, a partir disso, surgiu a ideia de criar um movimento a fim de que juntas pudessem ajudar umas as outras nessa procura. Assim, "em 30 abril de 1977 esse pequeño baluarte de mulheres fez sua primeira apresentação na praça. A partir de então sofreram toda classe de prepotências e intimidações, e foram obrigadas a se colocar em ronda, pois estava proibido ficar parado em grupos (BARRANCOS, 2008, p. 150, tradução nossa).

Nessa perspectiva, percebe-se que a prisão e o desaparecimento de pessoas fez com que as famílias dos desaparecidos iniciassem um processo diário na busca 
de informações a nível individual. Somente com a falta de respostas e o desespero causado pela incerteza é que os familiares - e nesse caso mais especificamente as mulheres, mães e avós dos desaparecidos - passaram a entender e tomar consciência do que realmente estava acontecendo em seu país, a compreender que os acontecimentos não faziam parte de uma realidade distante, longínqua, mas que batiam em suas portas. Assim inicia, então, a busca por novos métodos, novas formas de combater a repressão, que faz com que essas mulheres se organizem em grupos a fim de obter respostas a nível individual, mas também social e coletivo, e de transformar essa realidade que, até então, parecia inevitável e imutável.

Nesse sentido, assim como no Brasil com o Movimento Feminino pela Anistia, as mulheres foram pioneiras na luta pelos direitos humanos e pela redemocratização na Argentina e, "sem organização nem teorização prévia, se não apenas com uma prática, a princípio, quase inevitável e muito cotidiana, conseguem estabelecer formas não tradicionais de luta contra o poder ilegítimo nas mãos da ditadura militar" (ORIA, 1987, p. 95, tradução nossa).

Dora Barrancos (2008) explica que as Madres se preocuparam em destacar a ausência de caráter político em sua organização, a fim evitar a repressão estatal. Desse modo, salientavam que seu protesto se dava unicamente na condição de mães de desaparecidos, mantendo-se afastadas de qualquer identificação de cunho ideológico. Barrancos ressalta ainda que as Madres acreditavam que, em razão do conservadorismo dos agentes do estado, a repressão contra elas não seria tão severa, o que se provou verdadeiro apenas em parte.

Um dos fatores que vai desencadear a repressão estatal contra as Madres é justamente a novidade e a irreverência desse movimento, que rompe com as noções tradicionais do papel da mulher. Isso porque "as normas sociais assinalam que uma mulher deve sofrer e cultivar seu sofrimento no âmbito privado, de modo íntimo, com recato, resignação e fatalismo. Que a sua dor não incomode aos demais e menos ainda que desencadeie conflitos" (ORIA, 1987, p. 82-3, tradução nossa). A mulher devia sofrer no âmbito privado, na esfera íntima, jamais levando a sua dor para a "calle", nunca sofrendo com agressividade, pois esse é um atributo masculino, sendo "anormal" quando revelado nas mulheres. Consequentemente, no início do movimento algumas Madres foram vítimas da repressão estatal, a exemplo de Azucena Villaflor de DeVicente. Segundo Barrancos (2008, p. 151, tradução nossa), "lançadas ao mar, seus restos apareceram teimosamente na costa um tempo depois, sepultadas 
anonimamente, foram finalmente reconhecidas há apenas algum tempo".

A partir desse fato, então, as Madres e Abuelas passaram a lançar mão de táticas para evitar a repressão. Piera Paola Oria (1987) conta algumas curiosidades que permitiram às Madres e Abuelas reconhecerem-se quando ainda não tinham conhecido umas às outras, bem como a marcar encontros pelo telefone, reunir-se em locais públicos, etc. Segundo a autora, as Madres decidiram utilizar de um prego enferrujado na lapela para que soubessem, quando não se conheciam, que estavam diante de outra Madre. Para elas, esse símbolo fazia referência a Jesus Cristo e, portanto, ao sofrimento e à dor. Para além, as Madres utilizavam-se de códigos para se referirem aos lugares que frequentavam, e aprenderam a codificar, igualmente, os horários dos encontros quando falavam ao telefone. Sem parar aí, o símbolo das Abuelas - o lenço branco sobre a cabeça - foi mais um feliz acaso do que propriamente um plano longamente elaborado. Ante a pressa em reunirem-se nas "calles" com algo que as identificasse e sem tempo para a compra de lenços, as Abuelas decidiram utilizar as fraldas brancas de seus netos na cabeça. Assim, com o tempo, os lenços brancos se tornaram um símbolo das Madres e Abuelas.

Mas a engenhosidade dessas mulheres não parou aí. Dado que não contavam com o apoio da imprensa, as Madres e Abuelas tiveram a ideia de escrever nas cédulas informações sobre suas filhas e seus filhos desaparecidos, descrevendo nome, data e lugar de desaparecimento e local provável da prisão. Essa tática espalhava a informação para um grande número de pessoas e com muita agilidade, pois, por medo, os portadores repassavam as cédulas com incomum rapidez. Além disso, quando uma Madre ou Abuela era presa ou abordada pela polícia, um número significativo de mulheres se apresentava juntamente com ela. Assim, os agentes estatais não conseguiam cumprir sua função em razão do grande número de mulheres, e todas eram liberadas (ORIA, 1987).

É importante destacar que o movimento das Abuelas de Plaza de Mayo, por sua vez, surgiu dentro do movimento das Madres. Isso porque muitas mães que procuravam por filhas e noras que foram presas enquanto grávidas não tinham quaisquer notícias sobre o paradeiro delas, bem como de seus netos e netas. Assim, conforme Samantha Viz Quadrat (2003, p. 174), as Abuelas organizaram-se a partir da "percepção de que o desaparecimento de seus netos não eram casos isolados dentro da ditadura militar, mas sim um drama que estava alcançando proporções nacionais". Conforme Delgado (2013, p. 50, tradução nossa), "a organização estima 
que há mais de 400 crianças desaparecidas e seu objetivo é encontrar todas elas". No entanto, até o momento apenas 119 netos foram identificados, conforme informação constante no site das Abuelas de Plaza de Mayo1.

A relação entre a Igreja Católica e a Associação das Madres e Abuelas também merece destaque. Oria (1987, p. 104, tradução nossa) registra que as Madres e Abuelas, buscando "interlocutores válidos, no sentido de que a vida e as ações desses interlocutores eram sustentadas pelos mesmos valores que encorajavam sua própria luta, apelavam, sincera, esperançosa e inocentemente, aos membros hierárquicos da Igreja Católica". No entanto, na maioria dos casos, a hierarquia da Igreja estava publicamente engajada com o regime militar. Em seu desespero,

\begin{abstract}
Ao longo de dois anos, 1978 e 1979, as Avós da Plaza de Mayo escreveram 115 cartas para personalidades relevantes, civis, militares e eclesiásticas. Eles entregaram em mãos ou enviaram para o exterior 46 pastas completas com documentação detalhada da situação de cada criança localizada e da tarefa desenvolvida na busca. Ao longo desses dois anos, escreveram cinco vezes ao Papa (a primeira carta, de janeiro de 1978, a Paulo VI); das quatro cartas restantes, para João Paulo II, as duas últimas foram acompanhadas por pastas grossas com a documentação completa de cada caso e a situação de cada criança localizada. Nenhuma das cartas teve resposta, nem para consolá-las. Foram enviadas 14 cartas aos membros da hierarquia eclesiástica argentina: duas ao cardeal Aramburu, arcebispo de Buenos Aires, e duas ao cardeal Primatesta, arcebispo de Córdoba. Elas só tiveram resposta, compreensão e consolo de três bispos: Mons. De Nevares, Mons Hesayne e Mons. Novak (ORIA, 1987, p. 105, tradução nossa).
\end{abstract}

No entanto, embora a maioria dos membros da Igreja Católica tenha sido conivente com o regime autoritário, denunciando o trabalho das Madres e Abuelas ou, pelo menos, permanecendo inertes em vez de ajudá-las, houve exceções. A citar-se o exemplo do padre da Igreja de Guadalupe (Buenos Aires), que até hoje permanece no anonimato e que ajudava as mulheres a reunirem-se em sua paróquia. Segundo as Madres, quando se reuniam na Igreja, as luzes estavam sempre apagadas, de modo que podiam conversar em maior sigilo, no entanto, sempre que precisavam assinar ou ler algum documento, misteriosamente as luzes eram acesas. No momento em que precisavam sair novamente as luzes eram apagadas para que pudessem sair na penumbra (ORIA, 1987).

Em 1978 a Argentina sediou a Copa do Mundo de Futebol. O objetivo do Governo era vender uma imagem positiva do país para o mundo, demonstrando suas

\footnotetext{
1 A relação dos netos encontrados consta no site "Abuelas de Plaza de Mayo". Disponível em: https://abuelas.org.ar/caso/. Acesso em: 19 jun. 2016.
} 
qualidades e escondendo a violência com a qual a população era tratada. Igualmente, era uma boa oportunidade para "distrair" a população. No entanto, estando o país tomado pela imprensa de todo o mundo, não se podia evitar que as Madres chamassem atenção. "Foi assim que o mundo pode conhecer a existência das 'Madres Locas', como as autoridades de então desdenhosamente as chamavam" (ORIA, 1987, p. 85, tradução nossa).

Foi, então, graças à Copa que o mundo tomou conhecimento da luta dessas mães e avós que reivindicavam o direito básico a informação sobre seus filhos e netos. "Em muitos idiomas se escreveu sobre a dor e a valentia dessas mulheres que desafiavam a cortesia má dissimulada da polícia que lhes pedia amavelmente que se dispersassem" (ORIA, 1987, p. 85, tradução nossa). A partir daí, a voz das Madres ganhou o mundo e sua luta passou a ser cada vez mais reconhecida e apoiada pelos mais diversos organismos de proteção aos direitos humanos.

Ante ao exposto, não restam dúvidas de que as Madres e Abuelas exerceram vital importância na resistência ao regime autoritário na Argentina, podendo ser consideradas determinantes para a redemocratização do país, pois foram fundamentais na denúncia das violações de direitos humanos cometidas pelo governo, bem como na oposição ao regime. Elas foram responsáveis pela restituição de centenas de crianças, e pela devolução de suas histórias e identidades. Foram pioneiras na luta contra o regime militar argentino. Impulsionaram o desenvolvimento da genética forense, a fim de que seus netos pudessem ser identificados por meio de exames de sangue. Estimularam, com o fim do regime militar, o avanço da jurisprudência na seara dos direitos humanos, exigindo respostas e punições aos militares envolvidos na tortura e em desaparecimento de pessoas.

Essas Madres e Abuelas abriram caminhos para a reconstrução da cultura democrática e do respeito aos direitos humanos em seu país, agredindo o regime militar e transgredindo todos os padrões a elas impostos. Conforme aponta a Madre Nora de Cortiñas "a nossa simples presença desencadeava reações violentas" (ORIA, 1987, p. 130, tradução nossa). Tornando pública a sua função privada por meio da luta para encontrar seus filhos e netos, essas mulheres demonstraram que o pessoal é político. "Lançadas às ruas aterrorizadas da cidade, com seu modo de ver e pensar sobre as coisas, armadas apenas com su ador, esperança, fé e inocências, para eles o público e o privado nunca tiveram linhas que os dividissem" (ORIA, 1987, p. 111, tradução nossa). 
As mães e avós argentinas desafiaram diversos "monstros" a fim de reivindicar seus direitos, lutando contra um regime opressor numa época em que às mulheres era negada a ocupação do espaço público. As Madres e Abuelas, aproveitando-se do discurso patriarcal de que a mulher é naturalmente dócil e submissa, desafiaram a ordem posta, exibindo seu protesto bem diante dos "olhos" do governo militar, na "plaza", um local tipicamente masculino. Nesse sentido, ao fim de 1983, com o início do processo abertura, não se podia duvidar do papel fundamental desempenhados por essas mulheres. "Sua resistência arruinou qualquer cálculo sobre a docilidade das mulheres, ajudando a derrubar o mito da facilidade com que elas se dobram e obedecem" (BARRANCOS, 2008, p. 153, tradução nossa). Barrancos (2008, p. 153-4, tradução nossa) ainda salienta que "as mães e avós, que uniram rituais domésticos e ambientes públicos, deram novo sentido ao trânsito entre a casa e a praça".

A mensagem das Madres e Abuelas é clara: antes da repressão estavam confinadas à vida privada, hoje, encontram-se na "calle" na "plaza" e de lá não sairão. Tornaram-se "mulheres públicas", reconheceram-se como sujeitos políticos, assumiram seu "papel natural" e levaram-no às últimas consequências a ponto de causar o rompimento dessa visão idealizada da mulher. Com sua luta, as Madres e Abuelas se tornaram o principal símbolo da oposição na Argentina durante a ditadura, e ainda hoje desempenham um papel fundamental na consolidação da democracia no país e na preservação da memória argentina a respeito dos graves crimes perpetrados pelo regime autoritário.

\section{CONSIDERAÇÕES FINAIS}

Quando contemplamos uma obra de arte, quando lemos um livro, assistimos a um filme, enfim, buscamos compreender algo, nossa experiência, nossas vivências e expectativas fazem com que tenhamos uma visão singular a respeito do que se está observando. Assim, cabe indagar o que nos leva, com tanta frequência, a tornar invisível a presença da mulher na história.

Com esse estudo, buscou-se examinar a participação das mulheres na resistência às ditaduras no Brasil e na Argentina, bem como a importância e as consequências da atuação dos grupos de mulheres na oposição aos governos dos países em análise. 
Nesse sentido, foi possível constatar que em ambos os países as mulheres atuaram de diferentes maneiras durante a ditadura, seja no apoio a um golpe militar, seja no confronto direto ao governo autoritário, seja na oposição pacífica ao regime ditatorial. Assim, não se justifica a carência de uma bibliografia mais vasta sobre essas mulheres nos registros da história.

No Brasil, as mulheres foram pioneiras na luta contra a ditadura. A partir do Movimento Feminino pela Anistia outras instituições surgiram e várias entidades passaram a apoiar a bandeira pela anistia ampla e irrestrita, primeiramente erguida pelo MFA. Uma vez conquistada a anistia, presos políticos e funcionários públicos injustamente exonerados foram beneficiados, e os exilados puderam retornar com segurança ao país. Esse retorno, em especial em se tratando das mulheres exiladas, impulsionou a reivindicação de demandas tipicamente femininas, fazendo crescer o movimento feminista no país, bem como conquistando diversos direitos da mulher por meio da atuação do Conselho Nacional dos Direitos da Mulher (CNDM) na Assembleia Nacional Constituinte. Tema que, aliás, também é normalmente esquecido quando se trata de analisar os avanços da Constituinte.

$\mathrm{Na}$ Argentina, por sua vez, as Madres e Abuelas realizaram também um feito histórico: saíram da casa a "calle". Ocuparam a "plaza" para revelar sua dor, transformando o pessoal em político e transgredindo todas as normas - "naturais", morais, jurídicas - que lhes mantinha silentes, relegadas ao âmbito privado, alienadas da realidade. Graças à incansável luta das mães e avós de desaparecidos políticos, o mundo tomou conhecimento do horror da ditadura argentina, a genética avançou a fim de que os netos dessas mulheres pudessem ter suas famílias e identidades restituídas, a democracia venceu a opressão.

Não se duvida da relevância da participação das mulheres na resistência aos regimes autoritários brasileiro e argentino. Essas mulheres que se opuseram aos governos militares transgrediam, de uma só vez, duas regras: primeiro, uma regra "natural", que enxerga a mulher como naturalmente dócil e submissa; segundo, a regra autoritária, que proíbe qualquer tipo de manifestação por parte da população. Ao irem às ruas, ao levarem a sério o "dever materno", essas mulheres acabaram finalmente se reconhecendo enquanto sujeitos políticos. Precisamos, então, valorizar a história e a luta dessas e de outras mulheres, criando espaços para que elas atuem e façam história.

Por óbvio que a invisibilidade nas narrativas históricas não significa, de fato, 
que as mulheres permaneceram inertes, apáticas quanto aos rumos da história. $\mathrm{O}$ mundo não é tão simples assim. Prova disso está no retorno das mulheres às ruas durante as eleições de 2018, agrupadas em torno do movimento \#EleNão. Aqui, mais uma vez foram as mulheres que, insatisfeitas com os discursos proferidos por um candidato que não lhes representa, uniram-se contra a ameaça à democracia que se estabelece hoje em nosso país.

Contudo, as narrativas refletem, por óbvio, o sujeito autorizado a ser o portavoz da história: o homem, heterossexual e branco, responsável por registrar os acontecimentos e transformá-los em fatos importantes. É esse o discurso considerado legítimo, que confere um "selo" de importância às narrativas históricas. Na realidade, o apagamento das mulheres é imposto por um sistema social machista e patriarcal, que silencia a voz feminina a fim de mantê-la, para sempre, amordaçada. Ao reduzir a importância histórica da luta promovida pelas mulheres em prol do retorno democrático na América Latina, uma mensagem muito clara é transmitida: nessa democracia em construção, a presença feminina conta menos. Por isso, ainda hoje sofremos retaliações quando simplesmente nos fazemos presentes e exigimos que nossa voz seja ouvida.

Nesse cenário, cabe a nós, pesquisadoras, juristas, sujeitas de direito, superar a mordaça e nos fazer ouvir. Não basta ocupar os espaços que nos são dedicados. É preciso que arrombemos todas as portas que estão fechadas a nós, mulheres, fazendo nascer oportunidades onde até então só existiam vazios, ou não lugares. Difundir a luta das mulheres latino-americanas que se opuseram a regimes autoritários, machistas e conservadores, é ir aos poucos marcando nosso território, subvendo a ordem patriarcal que ainda tenta incessantemente nos calar.

\section{REFERÊNCIAS}

ABRÃO, Paulo. A Lei de Anistia no Brasil: as alternativas para a verdade e para a justiça. Acervo: Revista do Arquivo Nacional, Rio de Janeiro, RJ, vol. 24, n. 1, p. 119-138, jan./jun. 2011. Disponível em: <http://www.revistaacervo.an.gov.br/seer/index.php/info/issue/view/39>. Acesso em: 03 jun. 2015.

ARANTES, Maria Auxiliadora de Almeida Cunha. Resistência e dor. In: MERLINO, Tatiana; OJEDA, Igor (orgs.). Direito à memória e à verdade: Luta, substantivo feminino. São Paulo: Caros Amigos, 2010. Disponível em: http://www.dhnet.org.br/dados/livros/dh/livro_sedh_mulheres_ditadura.pdf. Acesso 
em: 02 jun. 2016.

ARQUIDIOCESE DE SÃO PAULO. Brasil: Nunca Mais. 12. ed. Petrópolis: Vozes, 1986.

BARRANCOS, Dora. Mujeres, entre la casa y la plaza. Buenos Aires: Sudamericana, 2008.

BRASIL. Comissão Nacional da Verdade. Brasília: CNV, 2014. v. 3.

BEAUVOIR, Simone de. 0 segundo sexo: fatos e mitos. Tradução de Sérgio Milliet. 8. ed. Rio de Janeiro: Nova Fronteira, 1991.

COLLING, Ana Maria. A resistência da mulher à ditadura militar no Brasil. Rio de Janeiro: Record; Rosa dos Tempos, 1997.

COSTA, Ana Alice Alcântara. O feminismo brasileiro em tempos de ditadura militar. In: PEDRO, Joana Maria; WOLFF, Cristina Scheibe (orgs.). Gênero, feminismos e ditaduras no Cone Sul. Florianópolis: Mulheres, 2010. Disponível em: $<$ https://bibliotecaonlinedahisfj.files.wordpress.com/2015/03/03062011-

101945feminismo-e-ditadurasfinal2.pdf>. Acesso em: 05 jun. 2016.

. O movimento feminista no Brasil: dinâmicas de uma intervenção política. In: MELO, Hildete Pereira de (et al). Olhares feministas. Brasília: Ministério da Educação, 2006.

DELGADO, Andrés. Memory and truth in human rights: the Argentina case. The issue of truth and memory in the aftermath of gross human rights violations in Argentina. 2012. 78 f. Dissertação (Mestrado em Artes) - Faculdade de Artes e Ciências, Universidade do Sul da Flórida, Tampa, Flórida (EUA). Disponível em: $<$ http://scholarcommons. usf.edu/cgi/viewcontent.cgi?article=5502\& context=etd $>$. Acesso em: 02 jun. 2016.

FLORES, Joaquín Herrera. Teoria crítica dos direitos humanos: Os direitos humanos como produtos culturais. Lumen Juris. Rio de Janeiro: 2009.

FREIRE, Nilcéa. Introdução. In: MERLINO, Tatiana; OJEDA, Igor (orgs.). Direito à memória e à verdade: Luta, substantivo feminino. São Paulo: Caros Amigos, 2010.

GONÇALVES, Danyelle Nilin. Os múltiplos sentidos de anistia. Revista Anistia Política e Justiça de Transição, Brasília, DF, 2009, n. 01, p. 272-95, jan./jun. 2009. Disponível em: <http://portal.mj.gov.br/main.asp?Team=\%7B67064208-D044-437B9F24-96E0B26CB372\%7D>. Acesso em: 07 jun. 2015.

MEIRELLES, Renata. Da memória para a história: experiências e expectativas de mulheres subversivas na ditadura militar. Prisma Jurídico, São Paulo, v. 10, n. 1, p. 111-134, jan./jun. 2011.

ORIA, Piera Paola. De la casa a la plaza. Buenos Aires: Nueva América, 1987. 
PEDRO, Joana Maria. Narrativas do feminismo nos países do Cone Sul (1960-1989). In: ; WOLFF, Cristina Scheibe (orgs.). Gênero, feminismos e ditaduras no Cone Sul. Florianópolis: Mulheres, 2010. Disponível em: <https://bibliotecaonlinedahisfj.files.wordpress.com/2015/03/03062011101945feminismo-e-ditadurasfinal2.pdf>. Acesso em: 05 jun. 2016.

PEIXOTO, Claudia C. Tomazi. Anistia, memória e direitos humanos: a experiência recente do Brasil à luz dos casos argentino e uruguaio. Revista Internacional de Direito e Cidadania, Erechim, RS, vol. 4, n. 11, p. 9-23, out. 2011. Disponível em: <http://reid.org.br/arquivos/00000279-01-claudia_reid-11.pdf>. Acesso em: 05 abr. 2015.

PERROT, Michelle. Os excluídos da história. Tradução de Denise Bottmann. $2^{\mathrm{a}}$ ed. Rio de Janeiro: Terra e Paz, 1988. p. 185-212.

As mulheres ou os silêncios da história. Tradução de Viviane Ribeiro. São Paulo: EDUSC, 2005.

Sair. In: DUBY, Georges; PERROT, Michelle. História das mulheres no ocidente: o século XIX. Tradução de Cláudia Gonçalves e Egito Gonçalves. Santa Maria da Feira: Edições Afrontamento, 1991. v. 4. p. 503-539.

QUADRAT, Samantha Viz. O direito à identidade: a restituição de crianças apropriadas nos porões das ditaduras militares do Cone Sul. História, Franca (SP), v. 22, n. 2, p. 167-181, 2003. Disponível em: $<$ http://www.scielo.br/scielo.php?script=sci_arttext\&pid=S010190742003000200010>. Acesso em: 18 maio 2016.

RIDENTI, Marcelo Siqueira. As mulheres na política brasileira: os anos de chumbo. Revista Tempo Social, São Paulo, v. 2, n. 2, p. 113-128, jul./dez. 1990. Disponível em: http://www.revistas.usp.br/ts/article/view/84806. Acesso em: 05 jul. 2016.

SANTOS, André Leonardo Copetti; LUCAS, Doglas Cesar. A (in)diferença no direito. Porto Alegre: Livraria do Advogado, 2015.

SARTI, Cynthia Andersen. Feminismo e contexto: lições do caso brasileiro. Cadernos Pagu, v. 16, p. 31-48, 2001. Disponível em: www.scielo.br/scielo.php?pid=S0104$83332001000100003 \&$ script=sci_arttext\&tlng=es. Acesso em: 16 jun. 2016.

. O início do feminismo sob a ditadura no Brasil: o que ficou escondido. In: XXI International Congress of LASA, Chicago, set. 1998. Disponível em: http://lasa.international.pitt.edu/LASA98/Sarti.pdf. Acesso em: 19 maio 2016.

SCHMINK, Marianne. Women in Brazilian Abertura Politics. Revista Signs, Chicago, EUA, v. 7, n. 1, p. 115-134, 1981. Disponível em: http://www.jstor.org/stable/3173512. Acesso em: 02 jul. 2016.

SCOTT, Joan W. A mulher trabalhadora. In: DUBY, Georges; PERROT, Michelle. História das mulheres no ocidente: o século XIX. Tradução de Cláudia Gonçalves e Egito Gonçalves. Santa Maria da Feira: Edições Afrontamento, 1991. v. 4. p. 443- 
475.

História das mulheres. In: BURKE, Peter (org.). A escrita da história: novas perspectivas. Tradução de Magda Lopes. São Paulo: Universidade Estadual Paulista, 1992. p. 63-95.

SKIDMORE, Thomas. Uma História do Brasil. 3. ed. São Paulo: Paz e Terra, 2000.

SOUSA, Jessie Jane Vieira de. Anistia no Brasil: um processo político em disputa. In: PAYNE, Leigh A.; ABRÃO, Paulo; TORELLY, Marcelo D. (orgs). A anistia na era da responsabilização: o Brasil em perspectiva comparada. Brasília: Ministério da Justiça, Comissão de Anistia; Oxford University, Latin American Centre, 2011. Disponível em: $<$ http://www.portalmemoriasreveladas.arquivonacional.gov.br/cgi/cgilua.exe/sys/start. htm? infoid=17\&sid=4>. Acesso em 17 maio. 2015. p. 188-210.

TELES, Janaína de Almeida. As disputas pela interpretação da Lei de Anistia de 1979. Revista Ideias: Dossiê: Um balanço crítico da redemocratização no Brasil, Campinas, SP, vol. 1, n. 1, p. 71-94, 2010. Disponível em: <http://www.ifch.unicamp.br/ojs/index.php/ideias/issue/view/2/showToc>. Acesso em: 03 jun. 2015.

WOLFF, Cristina Scheibe. Pedaços de alma: emoções e gênero nos discursos da resistência. Revista Estudos Feministas, Florianópolis, SC, v. 23, n. 3, p. 975-989, set./dez.
http://www.scielo.br/scielo.php?script=sci_arttext\&pid=S0104026X2015000300975\&lng=en\&nrm=iso\&tlng=pt. Acesso em: 12 jun. 2016. 